candidate refuses to co-operate with us, then it is proposed to "snow him under" at the polls.

I am satisfied that had this National Bureau been formed a year ago much of the terrible deprivations and sufferings that overtook our boys in the field would have been largely reduced; for had President McKinley had at his elbow a man in touch with all the leading health organizations of the States, as he would have, had this Bureau been formed as the Committee of the American Medical Association had it mapped out, a better selection for Army camps would also have been made.

While I do not wish to criticize at all the work of Surgeon. General Sternberg-for I consider it magnificent-yet, at the same time, I feel that had he had the aid of some one at head. quarters, in the President's Cabinet, who was a careful, conscientious medical man, that the medical record of the army would not have been surpassed in the history of active military campaigns.

With this view, I ask your readers everywhere to put into operation the necessary measures for explaining these matters to the Congressional candidates, and for those of the State Legislature, so that in the coming year our representatives can work more in harmony upon this all-important medical question-the establishment of a National Health Bureau.

Some of the present United States Senators and Representatives are warmly in favor of the bill advanced by the Committee of the American Medical Association, introduced by Senator Spooner, and we are satisfied that many of the other members of both the House and Senate would be as warmly committed to its provisions if they only knew its far-reaching beneficial results. Yours truly,

$$
\text { C. Henri Leonard, M.D. }
$$

\section{Another Cataractous Family.}

Wheeling, W. VA., Oct. 15, 1898.

To the Editor:-A bout two years ago, in the New York Med. ical Journal, I reported "A Cataractous Family," in which the mother, three daughters, and possibly two sons, have had cataracts at about the age of 40 .

I operated today on a mature cataract in the right eye of a man named Reason Goddard, farmer, aged 67. It had first begun to dim his sight sixteen years ago. One in the left eye is about half formed.

His father had cataracts in both eyes, well-matured, when he died at the age of 68 .

An older sister of the patient was blind from cataract and was operated on at about the age of 50 .

Another sister, aged about 60 , has a mature cataract in the right eye.

Two male cousins, sons of his father's brother, had cataracts in both eyes when about 60 years of age.

John L. Dickey, A.M., M.D.

\section{SOCIETY NEWS.}

Postponed.-The Southern Surgical and Gynecological Association has postponud its Memphis (Tenn.) meeting until Dec. 13,14 and 15,1898, on account of the prevalence of yeliow fever.

American Microscopical Society.-This society at its recent annual session, elected the following officers for the ensuing year President, Dr. William C. Krauss. Buffalo : first vice-president, Prof. A. M. Bleile, Columbus, O.; second vice-president, Dr. G. C. Huber, Ann Arbor, Mich.; secretary, Prof. Henry D. Ward, Lincoln, Neb. ; treasurer, Magnus Pflaum, Pittsburg; executive committee, Prof. S. H. Gage, Ithaca, Dr. A. Clifford Mercer, Syracuse, and Dr. V. A. Moore, Ithaca. its eighth annual meeting in Buffalo, N. Y., held September 13, 14 and 15, elected for president, Francis B. Bishop, Washington, D. C. ; vice-presidents, Ernest Wende, Buffalo, N. Y. ; William P. White, Boston, Mass. ; secretary, John Guerin, A uburn, N. Y. ; treasurer, Richard J. Nunn, Savannah, Ga.

Wayne County Medical Society.-At the regular meeting, held October 13, in Detroit, Dr. K. Gunsolus read a paper on "Cranial Abscess." He said that, in the early '70s, when he first began to practice medicine, he passed through an epidemic of cerebrospinal meningitis, in Monroe County, Mich. The epidemic began in the spring of the year and continued with more or less severity for about a year. Great numbers had been attacked and the mortality was high, many of the deaths being due, no doubt, to the formation of pus in the cranial cavity. No attempt at relief by surgical interference had been done, for brain surgery was then in its infancy. While there is an increasing field for the general surgeon in this branch of science, there is more work and more attainments to be accom. plished by the ear specialist in this direction than any other, for it is conceded, and statistics show, that more than one-half of the cases of cranial abscess arise from a suppurative process in the middle ear. As to the other causes of cerebral abscess, we have first, traumatism, more frequent than severe, though it may follow a slight injury and a long while after the injury has been received. In these cases the abscess is always found at the seat of injury. Another cause of cerebral abscess is caries or suppurative processes in the orbital cavity, the antrum of Highmore, or the nasal cavity. Boettcher reported a case where a cerebral abscess was secondary to an abscess of the lungs. Lastly, there are the so-called idiopathic cases, which some so stoutly deny having any existence. The doctor then entered into the symptoms, including the localizing symptoms by which it is possible to tell more or less accurately the location of the abscess, enumerated the diseases from which cra. nial abscess should be differentiated, and gave the treatment, which is the evacuation of the pus with good drainage, as in abscesses elsewhere. Drugs of any description amount to nothing.

\section{NECROLOGY.}

H. A. Gilman, M.D., for many years euperintendent of the Hospital for the Insane at Mount Pleasant, Iowa, died October 9. Dr. Gilman was a man of rare executive ability, and came to Iowa from the institution of like nature at Jacksonville, Ill., where he had been assistant physician fifteen years. The hospital at Mount Pleasant stands as a monument to his general capabilities as a manager. He was graduated from Dartmouth Medical College in 1867. He was 53 years old.

Nathan SMith Lincoln, M.D., University of Maryland, 1852, a well-known physician of Washington, D. C., died there October 3, aged 70 years. He was an emeritus professor of surgery to the Columbian University at the time of his death and was also a member of many medical societies, and of late years in high esteem as a consultant. He will be recalled by most of the profession as an attendant of President Garfield during the last months of his life.

Francis IJteber, M. D., an acting assistant-surgeon U. S. A., Judge Advocate.General Lieber's oldest son, died of typhoid fever at Fernandina, Fla., October 10.

Henry Clay Baker, M.D., Malvern, Ark., October 9.-C. M. Holmes, M.D., first assistant physician at the Northampton Hospital for the Insane, Northampton, Mass., October, 7, aged 49 years. - Charles L. Fox, M.D., Lowell, Mass., aged 28 years.--Calvin Morgan, M.D., Dugansville, Ky., October 3.-William Pratt Read, M.D., Philadelphia, October 8, aged 51 years.—John G. Stuart, M.D., Fortville, American Electro:Therapeutic Association.-This association, at Ind., October 7, aged 73 years. 